\title{
Conserved linkage of neurotrophin-3 and von Willebrand factor on mouse Chromosome 6
}

\author{
Lon L. Barrow, ${ }^{1}$ Karl Simin, ${ }^{1}$ Karen Mohlke, ${ }^{1}$ William C. Nichols, ${ }^{2}$ David Ginsburg, ${ }^{1,2,3}$ Miriam H. Meisler ${ }^{1}$ \\ ${ }^{1}$ Department of Human Genetics, 4708 Medical Sciences II, University of Michigan, Ann Arbor, Michigan 48109-0618, USA \\ ${ }^{2}$ Department of Internal Medicine, University of Michigan, Ann Arbor, Michigan 48109, USA \\ ${ }^{3}$ Howard Hughes Medical Institute, University of Michigan, Ann Arbor, Michigan 48109, USA
}

Received February 18, 1993; accepted February 25, 1993

Neurotrophin-3 and other neurotrophic factors contribute to the development and maintenance of the vertebrate nervous system by promoting localized neuronal survival. The human gene encoding neurotrophin3 , a highly conserved protein with complete amino acid identity in human, mouse, and rat, has been mapped to Chromosome (Chr) 12p13 (Maisonpierre et al. 1991). The mouse homolog, Ntf-3, was assigned to Chr 6 by use of a somatic cell panel (Ozcelik et al. 1991). We undertook the regional localization of $N t f-3$ in order to test it as a candidate for the mnd 2 mutation which we recently mapped to Chr 6; homozygosity for $m n d 2$ results in motor neuron disease due to degeneration of spinal motor neurons (Jones et al. 1993).

von Willebrand factor is a glycoprotein involved in blood coagulation that is both a carrier for factor VIII (antihemophilic factor) and a mediator of plateletvessel wall interaction (Ginsburg and Bowie 1992). The human gene $V W F$ (previous symbol $F 8 V W F$ ) is the most distally mapped gene on Chr $12 \mathrm{p} 13.3$ (NIH/CEPH Collaborative Mapping Group 1992). The locations of NTF3 and VWF suggested that they might be members of the conserved linkage group on mouse Chr 6 that includes 11 other genes from human 12p1213 (Nadeau et al. 1992; Elliott and Moore 1992).

$N t f-3$ was mapped by Southern blot analysis with a $B g l$ II RFLP between strains C57BL/6J $(3.6 \mathrm{~kb})$ and SPRET/Ei $(9.7 \mathrm{~kb}$; Fig. 1$)$. The $N t f-3$ probe was a 550 bp genomic fragment that was amplified from genomic DNA from strain C57BL/6J with primers based on the published nucleotide sequence (Hohn et al. 1990): primer $1,5^{\prime}(+250)$ AGG AGT TTG CCG GAA GAC TCT CTC AAT TCC (+279) 3'; and primer 2, 5' (+799) GCA ACC GTT TTT GAC CGG CCT GGC

Correspondence to: M.H. Meisler
TTC (+772) 3'. Amplification was carried out for 30 cycles with $1 \mathrm{~min}$ at $94^{\circ} \mathrm{C}$ and $1 \mathrm{~min}$ at $72^{\circ} \mathrm{C}$.

Two PCR-based genetic variants were used to map the $V w f$ locus. First, a length polymorphism between C57BL/6J (115 bp) and CAST/Ei (119 bp) was detected by direct amplification of $0.2 \mu \mathrm{g}$ of genomic DNA with primer 3 (5' TCC GGT GCC TTA CAG TCT GCT G $\left.3^{\prime}\right)$ and primer $4\left(5^{\prime}\right.$ TGT ACT CAG TAG TTC TTC CTA GGA G $3^{\prime}$ ). Primer 3 was end-labeled with $\gamma^{32} \mathrm{P}$ ATP ( $>5000 \mathrm{Ci} / \mathrm{mmol}$, Amersham) by use of polynucleotide kinase (New England Biolabs) as previously described (Roth et al. 1990). Amplification was carried out for 30 cycles with $1 \mathrm{~min}$ at $94^{\circ} \mathrm{C}, 30 \mathrm{~s}$ at $60^{\circ} \mathrm{C}$, and $30 \mathrm{~s}$ at $72^{\circ} \mathrm{C}$. PCR products were diluted threefold with formamide loading buffer and electrophoresed on $8 \%$ denaturing polyacrylamide gels. Second, a PCR RFLP between C57BL/6J and SPRET/Ei was detected by amplification of $0.2 \mu \mathrm{g}$ of genomic DNA with primer 5 from exon 28 (5' CCT TCA ATG GAT CCC AGT CCA AGG AGG AGG $\left.3^{\prime}\right)$ and primer 6 from intron $28\left(5^{\prime}-\right.$ GTT CTA GAC TCA AGC TTC TGG ATC TGT GTG $\left.3^{\prime}\right)$ in a 50- $\mu$ l reaction under previously described conditions (Ginsburg et al. 1989). Amplification was carried out for 35 cycles of $1 \mathrm{~min}$ at $94^{\circ} \mathrm{C}, 30 \mathrm{~s}$ at $55^{\circ} \mathrm{C}$, and $2 \mathrm{~min}$ at $72^{\circ} \mathrm{C}$. The PCR products were then digested with $R s a I$ and analyzed on a $4 \%$ agarose gel containing 3\% FMC NuSieve and 1\% BRL agarose (Fig. 1; Nichols et al., manuscript in preparation).

$N t f-3$ and $V w f$ were mapped with respect to the Chr 6 reference loci $m i$ and $R a f-1$, as well as several anonymous DNA markers. Microophthalmia (mi) was typed by hybridization with the 2.5 -kb genomic clone p24RI2.5, which directly flanks the insertion site of a transgenic insertional mutation at this locus (Krakowsky et al. 1993). This probe hybridizes with HindIII fragments of $4.5 \mathrm{~kb}$ in $\mathrm{C} 57 \mathrm{BL} / 6 \mathrm{~J}$ and $3.9 \mathrm{~kb}$ in SPRET/Ei (Fig. 1). A TaqI polymorphism (Jones et al. 1993) at the anchor locus Raf-1 (Kozak et al. 1984) was 


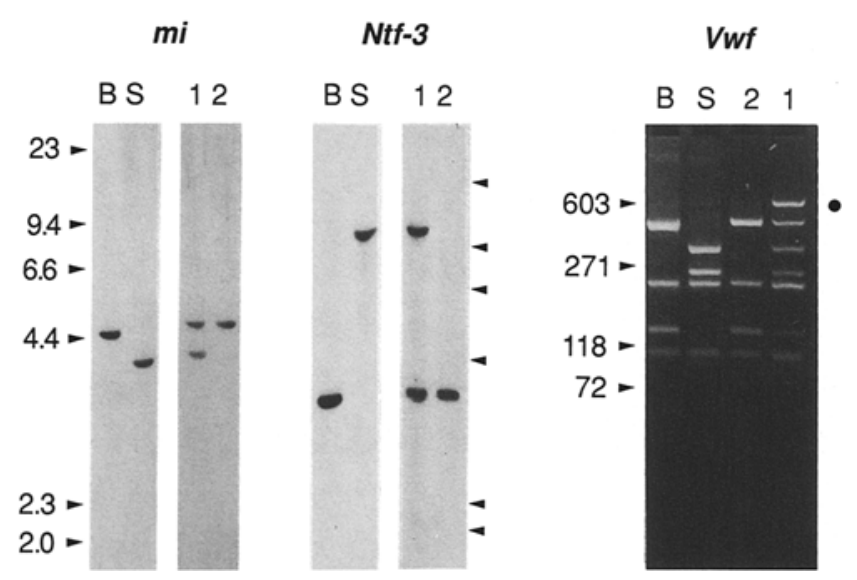

Fig. 1. Genetic variation at three loci on $\mathrm{Chr} 6$. For Southern blot analysis of $N t f-3$ and $m i$, genomic DNA was digested with $B g l I I$ and HindIII, respectively, and hybridized as described below. The positions of bacteriophage $\lambda$ HindIII fragments are indicated (kb). For analysis of $V w f$, genomic DNA was amplified by PCR, followed by digestion with $R s a \mathrm{I}$ as described in the text. A heteroduplex band is visible in heterozygous samples (solid circle). The positions of ФX174 Hae III fragments are indicated (bp). B, C57BL/6J; S, SPRET/Ei; 1, heterozygous backcross individual; 2, homozygous backcross individual. Methods. Genomic DNA was extracted by a salting out procedure (Miller et al. 1988), digested overnight with the appropriate restriction enzymes, and electrophoresed on $0.7 \%$ agarose gels with $10 \mu \mathrm{g}$ DNA per lane. DNA fragments were transferred to Zetaprobe GT (Bio-Rad Laboratories) nylon filters by capillary blotting (Southern 1975) and hybridized for $18 \mathrm{~h}$ at $65^{\circ}$ in $20 \mathrm{ml}$ of hybridization solution $(0.5 \mathrm{M}$ dibasic sodium phosphate, $1 \mathrm{~mm}$ EDTA, 7\% SDS, pH 7.2) with a final wash of $0.1 \times \mathrm{SSC}, 0.1 \%$ SDS at $65^{\circ} \mathrm{C}$ before the filters were exposed to X-ray film for $2-4$ days. Probes were labeled with $\alpha^{32} \mathrm{P}-\mathrm{dCTP}(>3000 \mathrm{Ci} / \mathrm{mmol}$, Amersham) by random oligoprimed labeling to $10^{9} \mathrm{cpm} / \mu \mathrm{g}$ (Feinberg and Vogelstein 1983).

detected by hybridization with the probe p627 (ATCC No. 41050). Primers for the microsatellite markers D6Mit8, D6Mit11, D6Mit12, and D6Mit14 were obtained from Research Genetics (Huntsville, Ala.). PCR analysis was carried out as described (Dietrich et al. 1992) except that $100 \mathrm{ng}$ of template DNA was used, and products were labeled by incorporation of $\alpha^{32} \mathrm{P}$-dCTP $(>3000 \mathrm{Ci} / \mathrm{mmol}$, Amersham) $(1 \mu \mathrm{Ci}$ per $10-\mu$ l reaction) with a 40 -fold reduction of unlabeled $\mathrm{dCTP}$ in the reactions.

$V w f$ was first mapped on a previously described $(\mathrm{C} 57 \mathrm{BL} / 6 \mathrm{~J}-m n d 2 \times \mathrm{CAST} / \mathrm{Ei}) \mathrm{F}_{2}$ mapping panel comprised of individuals homozygous for the Chr 6 mutation $m n d 2$ (Jones et al. 1993). Haplotypes from this panel are presented in Fig. 2A. The data localize $V w f$ to the interval between Raf-I and D6Mit14, with the indicated gene order: (centromere)-D6Mit8-(12.5 \pm 4.8)-Raf-1, D6Mit11-(2.1 \pm 2.1)-Vwf, D6Mit12-(10.4 \pm 4.4)-D6Mit14. Additional loci including $N t f-3$ were analyzed on a backcross between C57BL/6J-tg9257 and SPRET/Ei (Bain et al. 1993). Again, there were no recombinants between $V w f$ and D6Mit12 (Fig. 2B). The results demonstrate the gene order: (centromere)D6Mit8-(7.5 \pm 3.6)-mi- $(9.4 \pm 4.0)-V w f$, D6Mit12-(1.9 $\pm 1.9)-N t f-3$.

The results of the two crosses are combined in the map in Fig. 3, demonstrating gene order and relative positions of these loci. The positions of $m i$ and $R a f-1$

$$
\text { A. CAST/Ei } F_{2}(n=48)
$$
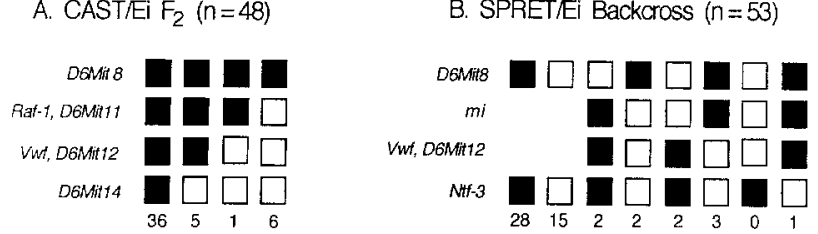

Fig. 2. Linkage data for loci on $\mathrm{Chr}$ 6. (A) Haplotypes from (C57BL/6J-mnd2 $\times$ CAST/Ei) $\mathrm{F}_{2}$ animals. (B) Tierred mapping of backeross progeny from the cross (C57BL/6J-tg9257 $\times$ $\mathrm{SPRET} / \mathrm{Ei}) \mathrm{F}_{1} \times \mathrm{C} 57 \mathrm{BL} / 6 \mathrm{~J}$. Each column represents one haplotype, and the number of mice with each haplotype is given at the bottom of each column. All of the $F_{2}$ progeny typed were homozygous for the Chr 6 locus mnd2 (Jones et al. 1993); haplotypes were inferred by assuming the absence of double crossovers between markers in this $20 \mathrm{~cm}$ region. Solid symbols, C57BL/6J homozygotes; open symbols, heterozygotes with C57BL/6J and CAST/Ei or SPRET/Ei alleles.

are consistent with the Chromosome 6 Committee map (Elliott and Moore 1992). Since $m n d 2$ is located proximal to Raf-l (Jones et al. 1993), the data eliminate $N t f-3$ as a candidate gene for this disorder. $N t f-3$ may be considered a candidate for the mutation opisthotonus, which maps to this region and results in loss of balance and early death (Green 1989; Elliott and Moore 1992).

Our data add two new loci to the conserved linkage group on human Chr 12p12-13 and mouse Chr 6 (Nadeau et al. 1992; Elliott and Moore 1992). It is interesting that the von Willebrand factor gene is located close to the telomere on human Chr 12 but at an internal position on mouse $\mathrm{Chr} 6$. Mapping this gene in

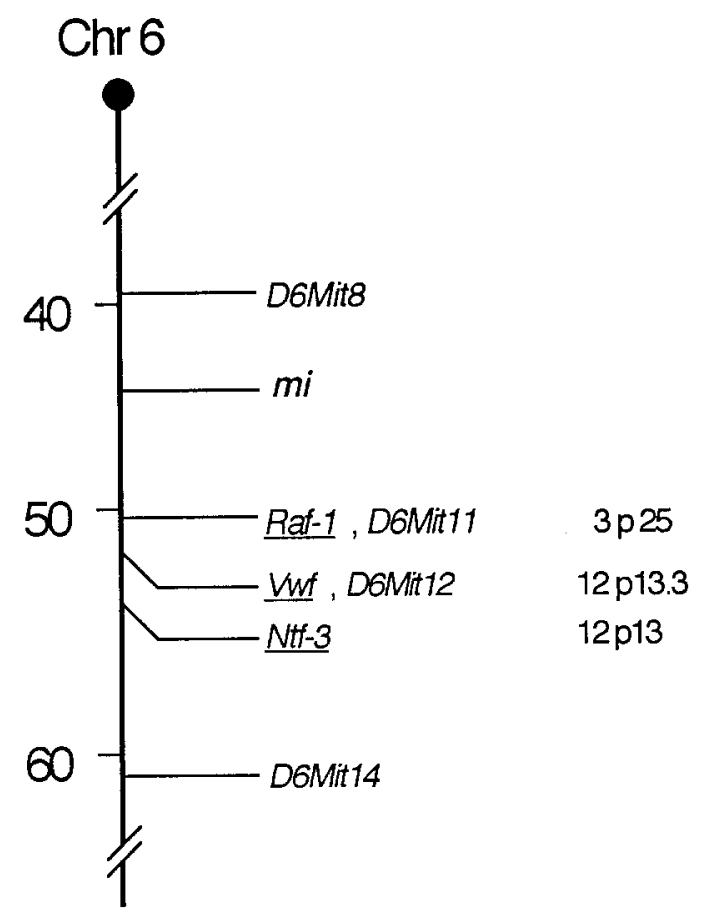

Fig. 3. Order of $\mathrm{Chr} 6$ loci based on data in Fig. 2. The approximate map positions are indicated in $\mathrm{cM}$ from the centromere (Elliott and Moore 1992). The positions of human genes homologous to the underlined mouse loci are indicated at the right (Bonner et al. 1984; NIH/CEPH Collaborative Mapping Group 1992; Maisonpierre et al. 1991). 
additional mammalian species would be of interest with regard to evolution of the $12 p$ telomere. The localization of $V w f$ reported here will facilitate ongoing investigations of clotting disorders in the mouse, including characterization of a mouse model for von Willebrand disease (Sweeney et al. 1990). There are no known clotting mutations in this region of Chr 6.

Acknowledgments. We are grateful to K.P. Anderson and J.B. Lingrel for providing the microophthalmia probe prior to publication. This work was supported by the Muscular Dystrophy Association (M.H. Meisler) and U.S. Public Health Service grants GM24872 (M.H. Meisler), HL39693 (D. Ginsburg), and HL08486 (W.C. Nichols). D. Ginsburg is a Howard Hughes Medical Institute Investigator. K. Mohlke is supported by the Genetics Training Program of the University of Michigan (T32GM07544). W.C. Nichols is a Judith Graham Pool Fellow of the National Hemophilia Foundation.

\section{References}

Bain, P.A., Meisler, M.H., Taylor, B.A., and Payne, A.H. (1993). The genes encoding gonadal and nongonadal forms of 3-Bhydroxysteroid dehydrogenase isomerase are closely linked on mouse chromosome 3 . Genomics 16 , in press.

Bonner, T., O'Brien, S.I., Nash, W.G., Rapp, U.R., Morton, C.C., and Leder, P. (1984). Two human homologs of the raf (mil) oncogene are located on human chromosomes 3 and 4. Science 223, 71-74.

Dietrich, W., Katz, H., Lincoln, S.E., Shin, H-S., Friedman, J., Dracopoli, N.C., and Lander, E.C. (1992). A genetic map of the mouse suitable for typing intraspecific crosses. Genetics 131, 423447.

Elliott, R.W. and Moore, K.J. (1992). Mouse Chromosome 6. Mammalian Genome 3 (Suppl): S81-S103.

Feinberg, A. and Vogelstein, B. (1983). A technique for radiolabeling DNA restriction fragments to high specific activity. Anal. Biochem. 137, 266-267.

Ginsburg, D. and Bowie, E.J.W. (1992). Molecular genetics of von Willebrand disease. Blood 79, 2507-2519.

Ginsburg, D., Konkle, B.A., Gill, J.C., Montgomery, R.R., Bockenstedt, P.L., Johnson, T.A., and Yang, A.Y. (1989). Molecular basis of human von Willebrand disease: analysis of platelet von
Willebrand factor mRNA. Proc. Natl. Acad. Sci. USA 86, 37233727.

Green, M.C. (1989). Catalog of mutant genes and polymorphic loci. In: Genetic Variants and Strains of the Laboratory Mouse M.F. Lyon and A.G. Searle, (eds) (New York: Oxford University Press), pp. 12-403.

Hohn, A., Leibrock, J., Bailey, K., and Barde, Y-A. (1990). Identification and characterization of a novel member of the nerve growth factor/brain-derived neurotrophic factor family. Nature 344, 339-341.

Jones, J.M., Albin, R.L., Feldman, E.L., Simin, K., Schuster, T.G., Dunnick, W.A., Collins, J.T., Chrisp, C.E., Taylor, B.A., and Meisler, M.H. (1993). mnd-2: A new mouse model of hereditary motor neuron disease. Genomics.

Kozak, C.A., Gunnell, M.A., and Rapp, U.R. (1984). A new oncogene, c-raf, is located on mouse Chromosome 6. J. Virol. 49, 297-299.

Krakowsky, J.M., Boissy, R.E., Neumann, J.C., and Lingrel, J.B. (1993). Insertional mutation of the mouse microophthalmia gene. Transgen. Res. 2, 14-20.

Maisonpierre, P.C., Le Beau, M.M., Espinosa, R. III, Ip, N.Y., Belluscio, L., De La Monte, S.M., Squinto, S., Furth, M.E., and Yancopoulos, G.D. (1991). Human and rat brain-derived neurotrophic factor and neurotrophin-3: gene structures, distributions, and chromosomal localizations. Genomics 10, 558-568.

Miller, S.A., Dykes, D.D., and Polesky, H.F. (1988). A simple salting out procedure for extracting DNA from human nucleated cells. Nucleic Acids Res 16, 1215.

Nadeau, J.H., Davisson, M.T., Doolittle, D.P., Grant, P., Hillyard, A.L., Kosowsky, M., and Roderick, T.H. (1992). Comparative map for mice and humans. Mammalian Genome 3, 480-536.

NIH/CEPH Collaborative Mapping Group (1992). A comprehensive genetic linkage map of the human genome. Science 258, 67-86.

Ozcelik, T., Rosenthal, A., and Francke, U. (1991). Chromosomal mapping of brain-derived neurotrophic factor and neurotrophin-3 genes in man and mouse. Genomics 10, 569-575.

Roth, M.S., Antin, J.H., Bingham, E.L., and Ginsburg, D. (1990). Use of polymerase chain reaction-detected sequence polymorphisms to document engraftment following allogenic bone marrow transplantation. Transplantation 49, 714-720.

Southern, E. (1975). Detection of specific sequences among DNA fragments separated by gel electrophoresis. J. Mol. Biol. 98, 503517.

Sweeney, J.D., Novak, E.K., Reddington, M., Takeuchi, K.H., and Swank, R.T. (1990). The RIIIS/J inbred mouse strain as a model for von Willebrand disease. Blood 76, 2258-2265. 